\title{
RESEÑA: SONIDOS DE LA DIÁSPORA. BLUES Y JAZZ EN TONI MORRISON, ALICE WALKER Y GAYL JONES. MARÍA ROCÍO COBO PIÑERO ${ }^{1}$
}

\author{
Alejandra Moreno Álvarez²
}

\begin{abstract}
María Rocío Cobo Piñero, Sonidos de la diáspora. Blues y jazz en Toni Morrison, Alice Walker y Gayl Jones. Sevilla: Arcibel, 2015. ISBN: 978-84-15335-580.
\end{abstract}

Sonidos de la Diáspora. Blues y Jazz en Toni Morrison, Alice Walker y Gayl Jones, de María Rocío Cobo Piñero (2015) representa un acercamiento poliédrico al blues, al jazz y a la literatura que surgió del contacto cultural en la diáspora africana. Su autora explora la influencia de estos dos géneros musicales en la obra literaria de Toni Morrison, Alice Walker y Gayl Jones. Ya decía Featherston que en la música se imbrican historias de la cultura donde los sonidos, la lengua y los cuerpos se encuentran (2005: 33). Los ritmos armónicos, las letras de las canciones, el baile al que estos incitan, etc. son un lenguaje en sí mismo, que Cobo Piñero conjuga inteligentemente junto con la literatura. Esto hace que el presente trabajo sea un material de gran valor para los estudios postcoloniales y dentro de estos, para los estudios diásporicos e híbridos, así como para los estudios culturales y de género. Graham Huggan se plantea en Interdisciplinary Measures (2008) que la interdisciplinaridad en los estudios postcoloniales es una práctica teórico-política innata a su campo (4). Ato Quayson distingue entre lo sinóptico (orientado hacia el concepto) y lo instrumental (aplicación pragmática) y pone de manifiesto que los estudios postcoloniales han sido altamente interdisciplinares en el

\footnotetext{
${ }^{1}$ Fecha de recepción: 01/12/2016.

Fecha de aceptación: 03/12/2016. ${ }^{2}$ Profesora Titular de Universidad, Departamento de Filología Inglesa, Francesa y Alemana, Universidad de Oviedo; $₫$ morenoalejandra@uniovi.es.
} 
sentido sinóptico utilizando materiales de diferentes disciplinas para deconstruir, reescribir e inscribir nuevas posibilidades al objeto de estudio en cuestión (2000: 25). Huggan, por el contrario, reconoce que la interdisciplinaridad en los estudios postcoloniales ha sido, en la mayoría de los casos, utilizada en un solo sentido, haciendo uso de ejemplos, pero sin conseguir una interdisciplinaridad y sí intradiscursos (Huggan 2008: 6). Cobo Piñero nos presenta un trabajo claramente interdisciplinar, a la par que discursivo, tanto en el sentido sinóptico como en el instrumental.

En la introducción, la autora deja claro que su propuesta es la de "contribuir al diálogo interdisciplinar entre música y literatura, vinculando los sonidos discordantes del blues y el jazz con las voces igualmente divergentes de Toni Morrison, Alice Walker y Gayl Jones" (9). La novedad de este trabajo radica en la atención prestada a la narrativa y a la música conjuntamente. La crítica literaria ha explorado el impacto del blues y el jazz en intelectuales afroestadounidenses, mayoritariamente varones, pero no con la profusión con la que lo hace Cobo Piñero y menos aún en obras de autoría femenina. Laura Viñuela en Una mirada al pop, al rock y a los diferentes estilos de música actual desde la perspectiva feminista, aportaba ya en 2003 una visión crítica y pormenorizada de las líneas de pensamiento más relevantes en cuanto al género y a la música popular desarrolladas en los ámbitos de la musicología y la sociología estadounidense e inglesa. Cobo Piñero va más allá, haciendo uso para tal fin de la música, de la literatura y de un corpus feminista que transgrede el canónico: oradoras abolicionistas como Sojourner Truth; pioneras de la literatura negra estadounidense como Zora Neale Hurston; activistas de los setenta como Angela Davis; musicólogas que abogan por el papel de las instrumentistas en el jazz como Sherrie Tucker, Linda Dhal; académicas y feministas como bell hooks, Barbara Christian o Patricia Hill Collins.

En cuanto al título, el hecho de que la autora utilice la palabra sonidos y diáspora seguido de un subtítulo encabezado por dos géneros que engloban dichos sonidos, el blues y el jazz, y tres autoras que representan la diáspora es más que acertado. El termino diáspora marca el concepto de estar en ruta, de venir de algún lado, de un espacio con reminiscencias del pasado y de un hábitat nuevo que ocupar y que, incluso, al igual que el presente trabajo, puede estar camino de crear un nuevo marco, como es la 
interdisciplinaridad. Cobo Piñero trabaja a lo largo de todo el libro con el juego de palabras que en su día hiciera Paul Gilroy (1993), root/route, a la par que visibiliza y da voz al pasado, presente y futuro.

Los nueve textos seleccionados y desgranados a lo largo de tres capítulos: Toni Morrison: música, ficción y testimonio; Alice Walker: la reivindicación de los referentes femeninos; Gayl Jones y la liberación de las voces, acentúan el carácter oral y "musicalizan memorias de opresión racial, sexual y de clase, a partir de los ritmos precursores africanos" (Cobo Piñero 2015: 9). La música y la literatura se convierten en un espacio de empoderamiento, que Cobo Piñero muestra al público lector. Desde el punto de vista histórico, Cobo Piñero repasa de forma diacrónica, los inicios del Blues Clásico en el sur de Estados Unidos, el Jazz de Nueva Orleans y de Harlem, el swing que precedió a la Primera Guerra Mundial, el bepop que le siguió, el rhythm and blues de los años cincuenta y las freedom songs del Movimiento por los Derechos Civiles (10). La literatura simula ser la partitura que dicta la música y que al mismo tiempo pone letra a la música creada, sin dictaminar qué va primero. En el primer capítulo, Cobo Piñero explora la construcción del discurso en torno a la alteridad y su representación artística a principio del siglo XX. La autora acomete un estudio de tres novelas de Morrison: The Bluest Eye (1970), Song of Solomon (1977) y Jazz (1992), donde los personajes femeninos que habitan estas obras hacen frente al yo construido y al yo propio; yoes que se debaten entre las tradiciones de la comunidad negra y la opresión racial de la sociedad blanca. Morrison hace uso de la jerga, la improvisación, la antífona, la síncopa o la repetición, todos ellos recursos jazzísticos:

Cuando el cliente llega y Violet está enjabonando el cabello, fino y canoso, murmurando, "ipor Dios!," cada vez que interrumpe [breaks] el flujo de conciencia de la señora mayor, Violet recoloca la cuerda [cord] que sujeta la puerta del fogón y ensaya la súplica del mes para conseguir atrasar el pago del alquiler...se sienta junto a las pajareras y escucha a los niños que juegan [play]. (Morrison en Cobo Piñero 2015: 93)

El segundo capítulo tiene como eje Meridian (1976), The Color Purple (1982) y You Can't Keep a Good Woman Down (1981) de Alice Walker. La literatura y la música representan aquí un acto político reivindicativo, que clama visibilizar, al mismo tiempo 
que ocupar, la presencia de las mujeres en los ámbitos culturales e históricos. Cobo Piñero desgrana "las estrategias de autoafirmación ante situaciones tan diversas como la apropiación cultural en la música, las consecuencias de amoldarse a los preceptos de la clase media, el lugar de la mujer negra en la educación elitista, [...]en una sociedad patriarcal que las cosifica" (147).

Tras la descripción de la otredad de las mujeres negras, tanto músicas como literatas, pasando por el reclamo de visibilizar y ocupar espacios propios, el tercer capítulo se ocupa de inscribir nuevas interpretaciones al legado de la esclavitud. Para ello Cobo Piñero hace uso del blues y de Corregidora (1975), Eva's Man (1976) y Song for Anninho (1981) de Gayl Jones. Dentro de un marco postestructuralista, estas obras hacen uso del pastiche, tomando prestada la jerga del blues, como quoting, donde haciendo uso de citas que denotan la concepción estereotipada de la mujer, la narradora, a la par que Jones, repiten constantemente con el fin de desconstruir el discurso patriarcal normativo social y cultural. El blues se convierte en el medio para que con una lectura a contra pelo, los personajes y el público lector visualicen la subyugación que reside en los recuerdos. Son éstos los que buscan un lenguaje propio "y un nuevo enfoque: el de las personas oprimidas" (Cobo Piñero 2015: 217).

Cobo Piñero da voz a los recuerdos y crea un nuevo lenguaje haciendo uso de la música y de la literatura. Asimismo, ilustra la obra con imágenes de anuncios y carteles de la época, que enriquecen el estudio. Sonidos de la Diáspora: Blues y Jazz en Toni Morrison, Alice Walker y Gayl Jones contribuye a ampliar el necesario diálogo interdisciplinar entre música y literatura. Y lo que es más importante, visibiliza y da voz a las autoras y cantantes afroestadounidenses cuyas obras dejaron una impronta sin parangón en los Estados Unidos del siglo XX.

\section{Referencias bibliográficas}

Cobo Piñero, Rocío. 2015. Sonidos de la Diáspora. Blues y Jazz en Toni Morrison, Alice Walker y Gayl Jones. Sevilla: ArCiBel Editores. 
Featherstone, Simon. 2005. Postcolonial Cultures. Edinburgh: Edinburgh University Press.

Gilroy, Paul. 1993. The Black Atlantic: Modernity and Double Consciousness. Cambridge: Harvard University Press.

Huggan, Graham. 2008. Interdisciplinary Measures. Literature and the Future of Postcolonial Studies. Liverpool: Liverpool University Press.

Quayson, Ato. 2000. Postcolonialism: Theory, Practice a Process? Cambridge: Polity Press.

Quayson, Ato, ed. 2013. A Companion to Diaspora and Transnationalism. Hoboken, NJ: Wiley-Blackwell.

Viñuela, Laura. 2003. La perspectiva de género y la música popular: dos nuevos retos para la musicología. Oviedo: KRK. 